\title{
Salinity Effects on Bud Yield and Vegetative Growth of Artichoke (Cynara scolymus L.)
}

\author{
Leland E. Francois \\ U.S. Department of Agriculture, Agricultural Research Service, U.S. Salinity \\ Laboratory, 4500 Glenwood Drive, Riverside, CA 92501
}

Additional index words. salt tolerance, soil salinity, ion accumulation

\begin{abstract}
Globe artichokes recently have been planted in the irrigated desert area of southern California. Soils in this area are, or have the potential to become, highly saline from the application of saline irrigation water. Thus, a 2-year field plot study was conducted. A control and five saline treatments were imposed by irrigation with waters that contained equal weights of $\mathrm{NaCl}$ and $\mathrm{CaCl}_{2}$. Bud yield and vegetative growth were measured. For the two years, relative bud yield was unaffected up to a soil salinity of 6.1 $\mathbf{d S} \cdot \mathbf{m}^{-1}$ [electrical conductivity of the saturated soil extract (EC,)]. Each unit increase in salinity above $6.1 \mathrm{dS} \cdot \mathrm{m}^{-1}$ reduced yield by $11.5 \%$. These results place artichoke in the moderately salt-tolerant category. Yield reduction was attributed primarily to reduced bud weight rather than bud count. Vegetative growth was more tolerant to salt stress than was bud production. Chloride concentration in midrib and blade tissue increased as salinity increased.
\end{abstract}

Until recently, globe artichoke production in the United States has been confined to perennial plantings in central California coastal counties, where temperatures are uniformly mild in summer and relatively frost-free in winter. While cultural practices with these perennial plantings have resulted in a harvest season that is generally continuous throughout the year (Ryder et al., 1983), high temperatures during September and October can significantly reduce bud production during November to February.

During this reduced production period in the coastal area, market prices are favorable and a warmer winter climate in the desert has resulted in the recent development of an artichoke industry in these areas. In $1991,=200$ ha of artichokes were grown in the Imperial and Coachella valleys of California (Mayberry and Gonzalez, 1992). Whereas vegetative propagation is mostly used in the central coastal area, artichokes in the south are produced from seed-propagated cultivars.

Artichoke plantings in this arid southern California region may be on soils where salinity problems already exist or may develop from the use of saline irrigation water. While preliminary studies of salt stress on artichoke growth have been conducted with pot culture in the greenhouse (Graifenberg et al., 1993), they provide little information on the effect of salinity in the field where climatic conditions are significantly different. Since salt tolerance data are not available to adequately predict

Received for publication 31 May 1994. Accepted for publication 9 Sept. 1994. The cost of publishing this paper was defrayed in part by the payment of page charges, Under postal regulations, this paper therefore must be hereby marked advertisement solely to indicate this fact. yield responses under field conditions, a 2year field plot study was initiated to determine the effect of salinity on yield and vegetative growth. A salinity-induced Ca deficiency observed during this study has been previously reported (Francois et al., 1991).

\section{Materials and Methods}

Artichoke seed used in this study was the germplasm breeding line 86-024 released in 1986 by the Agricultural Research Service, U.S. Dept. of Agriculture. Seed of this breeding line is from the fourth generation of a within-line sib pollination of an original cross between an unidentified line from France and an Italian line obtained from V. Rubatzky, Univ. of California, Davis.

Seed were planted 22 Sept. 19X6 and 17 Sept. 1987 in 18 level field plots located at the Irrigated Desert Research Station, Brawley, Calif. Each plot $(6 \times 6 \mathrm{~m})$ contained six rows $0.9 \mathrm{~m}$ apart with seed placed $0.15 \mathrm{~m}$ apart within each row. After establishment, the seedlings were thinned to $0.75-\mathrm{m}$ spacing within each row. This plant spacing provided a population of $\approx 14,000$ plants/ha. Plot soil was a Holtville clay [clayey over loamy, montmorillonitic (calcareous), hyperthermic Typic Torrifluvent]. Each plot was enclosed by acrylic-fortified fiberglass borders that extended $0.75 \mathrm{~m}$ into the soil. The fiberglass borders protruded $0.15 \mathrm{~m}$ above the soil level of the plot and were covered with a berm 0.18 $\mathrm{m}$ high and $0.60 \mathrm{~m}$ wide. Walkways, $1.2 \mathrm{~m}$ wide between plots, and good vertical drainage effectively isolated each plot.

Before planting, triple super-phosphate was mixed into the top $0.25 \mathrm{~m}$ of soil at the rate of $73 \mathrm{~kg} \mathrm{P} / \mathrm{ha}$. To ensure adequate $\mathrm{N}$ fertility throughout the experiment, $\mathrm{Ca}\left(\mathrm{NO}_{3}\right)_{2}$ was added at each irrigation at $0.14 \mathrm{~kg} \mathrm{~N} / \mathrm{ha}$ per millimeter of water applied. The soil contained adequate levels of $\mathrm{K}$, so no additional $\mathrm{K}$ was added.

The design consisted of six treatments replicated three times in a randomized completeblock design. At the time of planting each year, the soil profiles in each plot had been differentially presalinized with the same quality irrigation waters that were to be used throughout the study. To assure good germination, $90 \mathrm{~mm}$ of low-salinity water $(1.4$ $\mathrm{dS} \cdot \mathrm{m}^{-1}$ ) was applied to all plots before planting to leach salts below the seed bed and also after planting to prevent soil crusting.

About 35 days after planting, when the plants were at the three- to four-leaf stage of growth, differential salivation was resumed. Irrigation water salinities were increased stepwise in two increments 14 days apart to achieve the desired salt concentrations. Equal weights of $\mathrm{NaCl}$ and $\mathrm{CaCl}_{2}$ were added to Colorado River water to obtain six irrigation waters with electrical conductivities $\left(\mathrm{EC}_{\mathrm{iw}}\right)$ both years of 1.4 (control), 2.0,4.0,6.0, 8.0, and $10.0 \mathrm{dS} \cdot \mathrm{m}^{-1}$. During both growing seasons, all plots were irrigated about every 3 to 4 weeks to keep the soil matric potential of the control treatments above $-85 \mathrm{~J} \cdot \mathrm{kg}^{-1}$ in the 0.15 - to $0.30-\mathrm{m}$ zone. Tensiometers were used to monitor soil matric potential and to guide irrigation frequent $y$. The total amount of irrigation water applied during each growing season was $563 \mathrm{~mm}$ in 1986-7 and $463 \mathrm{~mm}$ in 1987-88.

The electrical conductivity of the saturated-soil extract $\left(\mathrm{EC}_{\mathrm{e}}\right)$ was determined on soil samples taken three times each year during the growing season. Samples were taken within the plant row in $0.3-\mathrm{m}$ increments to a depth of $0.9 \mathrm{~m}$. The average $\mathrm{EC}_{\mathrm{e}}$ values over the course of the experiment were $4.6,6.6,7.4,8.7,10.6$. and $11.6 \mathrm{dS} \cdot \mathrm{m}^{-1}$ in $1986-87$, and $4.4,5.9,8.3$, 10.4 , I I .3, and $13.8 \mathrm{dS} \cdot \mathrm{m}^{-1}$ in $1987-88$ for the six treatments.

The mean daytime high for the month preceding the first harvest was 23C in 1987 and 26C in 1988. During the harvest period, the mean highs were $31 \mathrm{C}$ in 1987 and 30C in 1988. The cumulative Class A pan evaporation during the same preharvest and harvest periods was 218 and $370 \mathrm{~mm}$ in 1987 and 214 and $466 \mathrm{~mm}$ in 1988.

Artichokes buds were harvested when their circumference exceeded $250 \mathrm{~mm}$. The first harvests were on 20 Mar. 1987 and 17 Mar, 1988. Subsequent harvests were made at 5- to 6-day intervals for the next 48 days in 1987 and 30 days in 1988. The onset of plant senescence and delayed bud development determined when harvests were discontinued.

At harvest, each artichoke was weighed and its circumference measured. In addition, the outer bracts of each artichoke were removed to determine Ca-deficiency damage to the inner bracts (Francois et al., 1991 ). If buds exhibited damage, they were weighed separately from the nondamaged buds. Damaged buds were not included in total yield determination.

After all marketable-sized buds were harvested, total vegetative growth from the har- 
vest area was weighed and a subsample dried in a forced-air dryer at $70 \mathrm{C}$ to determine water content.

Mature, fully expanded leaves were sampled midway through the 1987 and 1988 harvests. Leaf midribs were removed from the rest of the leaf blade for separate analysis. All sampled material was washed, dried at 70C, and finely ground in a blender. Chloride contents were determined on $0.1 \mathrm{M}$ nitric acid in $1.7 \mathrm{M}$ acetic acid extracts of the leaf material by the Cotlove ( 1963) coulometric-amperometric titration procedure. Nitric-perchloric acid digests of the sampled material were analyzed for $\mathrm{Ca}, \mathrm{Na}, \mathrm{Mg}$, and $\mathrm{K}$ by atomic absorption spectrophotometry.

\section{Results and Discussion}

Total bud yield was significantly reduced at soil salinity levels $>7.4 \mathrm{dS} \cdot \mathrm{m}^{-1}$ in 1987 and $5.9 \mathrm{dS} \cdot \mathrm{m}^{-1}$ in 1988 (Table 1). Yields measured at the lower salinities were similar to average commercial yields in the Imperial Valley of California both years, i.e., $15.4 \mathrm{t} \cdot \mathrm{ha}^{-1}$ (Mayberry and Gonzalez, 1992). However, like most crops, artichoke yields will vary, depending on climate, soil conditions, and cultural practices.

Although the number of buds per plant was significantly affected by increased levels of salinity only in 1988, the higher salinity treatments in both years showed a tendency to produce fewer harvestable buds per plant. This result seems to indicate that bud count may only contribute significantly to yield reduction when soil salinities are higher than those imposed in this study. Since bud circumference was only slightly, although significantly, reduced with increased salinity levels, the reduction in total yield was accounted for primarily by the significant reduction in the weight of individual buds (Table 1).

Total yield data for each year were statistically analyzed with a piecewise linear response model (van Genuchten and Hoffman, 1984). The tolerance thresholds (the maximum allowable EC, without a yield decline) and the yield decline above the thresholds were nearly the same for both years. Therefore, the yield data for both years were combined and analyzed. The combined data indicate a threshold of $6.1 \mathrm{dS} \cdot \mathrm{m}^{-1}$ and a yield decline of $11.5 \%$ for each unit increase in soil salinity above the threshold (Fig. I). Relative yield (Yr) for any EC, exceeding the threshold of $6.1 \mathrm{dS} \cdot \mathrm{m}^{-1}$ can be calculated with the equation in Fig. 1.

Threshold and slope analyses tend to agree generally with those reported by Graifenberg et al. (1993), when artichokes were grown in the greenhouse. Their threshold and slope were $4.9 \mathrm{dS} \cdot \mathrm{m}^{-1}$ and $10.7 \%$, respectively.

When Ca-deficient buds, which were not included in the threshold and yield decline analyses, were added to total yield, the tolerance threshold increased to $7.4 \mathrm{dS} \cdot \mathrm{m}^{-1}$ and the yield decline per unit increase in salinity decreased to $8.0 \%$. This perceived increase in tolerance was not unexpected because the number of Ca-deficient buds increased signifi- cantly each year as salinity increased (Francois et al., 1991). Since these buds were judged to be unmarketable, the higher the soil salinity the greater the number of buds eliminated from final yield analysis.

According to the salt tolerance classification scheme of Maas and Hoffman (1977), artichoke would be classified as moderately tolerant. Thus, artichokes are in a higher tolerance category than most other vegetable crops (Francois and Maas, 1993).

Desert-grown artichokes increase in toughness and decrease in flavor with the onset of warm weather in spring (Mayberry and Gonzalez, 1992). These physiological changes tended to occur earlier in the harvest season with buds on the higher-salinity-treated plants. Not only did the buds become tough and woody, but they were slow to develop to meet harvest criteria.

The combined 2-year data for vegetative dry weight indicate an average threshold of 7.8 $\mathrm{dS} \cdot \mathrm{m}^{-1}$ and a growth decline of $8.3 \%$ for each unit increase in $\mathrm{EC}_{\mathrm{e}}$ above that threshold (Fig. 1 ). These data show vegetative growth is more tolerant to salt stress than bud production. An $\mathrm{EC}_{\mathrm{e}}$ of $7.8 \mathrm{dS} \cdot \mathrm{m}^{-1}$, the threshold for vegetative growth, would show no vegetative reduction but would have reduced bud yield by $20 \%$.

Chloride concentration in the leaves tended

Table 1. Bud yield characteristics of artichokes grown at six salinity levels during two growing seasons.

\begin{tabular}{|c|c|c|c|c|}
\hline $\begin{array}{l}\text { Soil salinity } \\
\left(\mathrm{EC}_{\mathrm{e}}\right) \\
\left(\mathrm{dS} \cdot \mathrm{m}^{-1}\right) \\
\end{array}$ & $\begin{array}{c}\text { Total bud } \\
\text { yield } \\
\left(\mathrm{t} \cdot \mathrm{ha} \mathrm{I}^{\prime}\right) \\
\end{array}$ & $\begin{array}{c}\text { Avg bud w1 } \\
(\mathrm{g})\end{array}$ & $\begin{array}{c}\text { Bud } \\
\text { no./plant }\end{array}$ & $\begin{array}{c}\text { Avg bud } \\
\text { circumference } \\
(\mathrm{mm})\end{array}$ \\
\hline & & 1987 & & \\
\hline 4.6 & 16.7 & 211 & 6.1 & 289 \\
\hline 6.6 & 16.8 & 203 & 6.6 & 287 \\
\hline 7.4 & 16.1 & 206 & 7.3 & 287 \\
\hline 8.7 & 10.0 & 190 & 5.9 & 282 \\
\hline 10.6 & 9.0 & 179 & 6.3 & 279 \\
\hline 11.6 & 5.3 & 178 & 5.4 & 274 \\
\hline \multirow[t]{2}{*}{ Significance } & $\mathrm{L}^{* * *}$ & $\mathrm{~L}^{* * *}$ & NS & $\mathrm{L}^{* * *}$ \\
\hline & & 1988 & & \\
\hline 4.4 & 17.1 & 256 & 5.2 & 274 \\
\hline 5.9 & 17.7 & 234 & 6.4 & 275 \\
\hline 8.3 & 13.3 & 214 & 5.1 & 275 \\
\hline 10.4 & 8.5 & 189 & 5.2 & 264 \\
\hline 11.3 & 5.2 & 180 & 4.9 & 258 \\
\hline 13.8 & 4.1 & 179 & 4,0 & 260 \\
\hline Significance & $\mathrm{L}^{* * *}$ & $\mathrm{~L}^{* * *}, \mathrm{Q}^{*}$ & $\mathrm{~L}^{*}$ & $\mathbf{L}^{* *}$ \\
\hline
\end{tabular}

${ }^{2} \mathrm{~L}=$ linear; $\mathrm{Q}=$ quadratic.

$\mathrm{NS}, *, * *, * * *$ Nonsignificant or significant at $\mathrm{P}=0.05,0.01$, or 0.005 , respectively

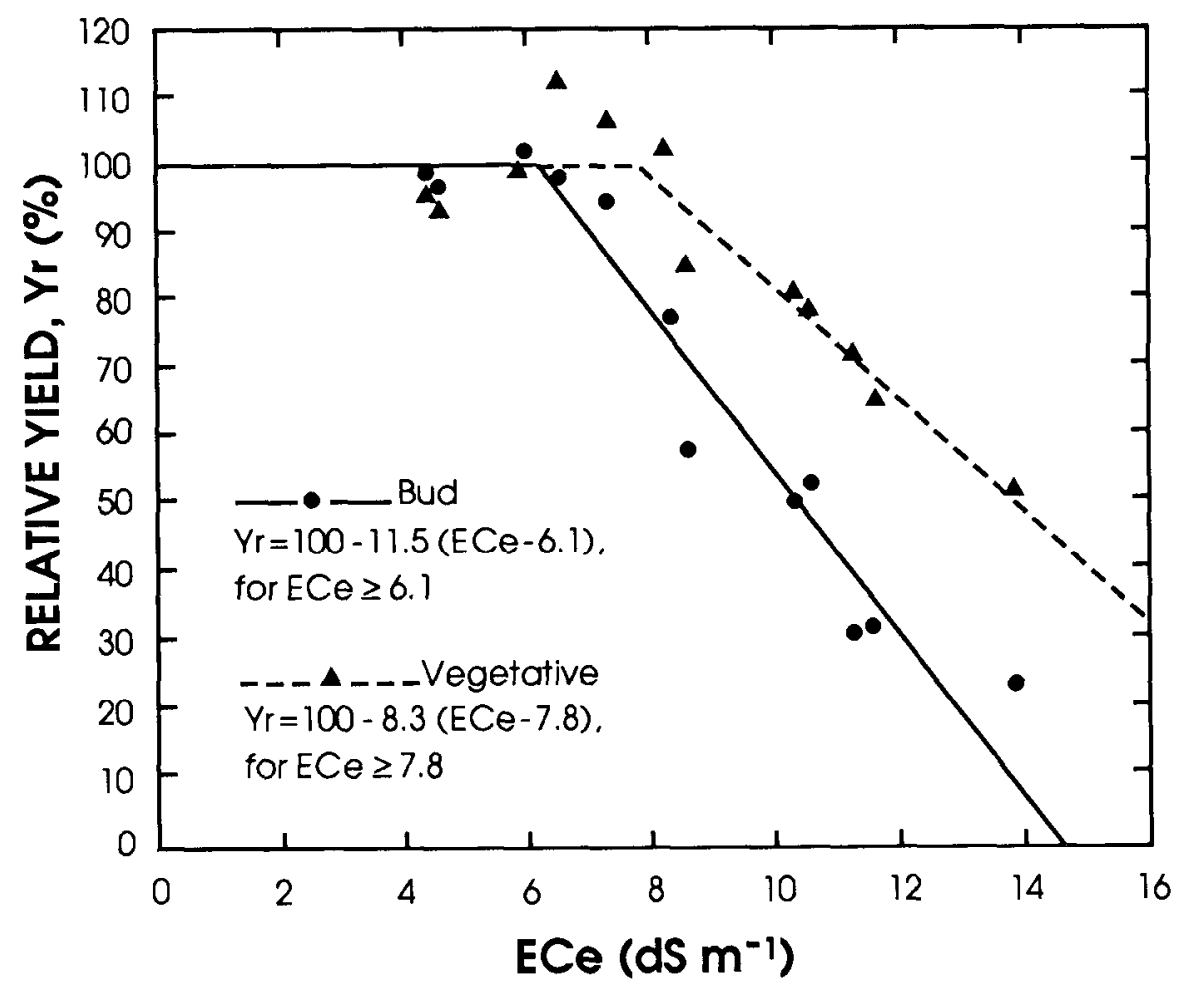

Fig. 1. Relative bud yield and vegetative growth of artichoke as a function of increasing soil salinity. 
Table 2. Chloride concentration of leaf blades and midribs from artichokes grown at six salinity levels in 2 years.

\begin{tabular}{lcc}
\hline $\begin{array}{l}\text { Soil salinity } \\
\left(\mathrm{EC}_{\mathrm{e}}\right)\end{array}$ & \multicolumn{2}{c}{$\mathrm{Cl}^{\mathrm{C} \text { concn }}$} \\
$\left(\mathrm{dS} \cdot \mathrm{m}^{1}\right)$ & 1987 & Blade \\
\cline { 2 - 3 } & Midrib & \\
4.6 & 1751 & 1086 \\
6.6 & 1902 & 1300 \\
7.4 & 2057 & 1310 \\
8.7 & 1920 & 1315 \\
10.6 & 2099 & 1486 \\
11.6 & 2072 & 1462 \\
Significance & $\mathrm{L}^{* * *}$ & $\mathrm{~L}^{* * *}$ \\
& 1988 & \\
4.4 & 1680 & 1019 \\
5.9 & 1683 & 1190 \\
8.3 & 1692 & 1320 \\
10.4 & 1687 & 1172 \\
11.3 & 1855 & 1360 \\
13.8 & 2094 & 1346 \\
Significancc & $\mathrm{L}^{*}$ & $\mathrm{~L}^{* *}$ \\
\hline
\end{tabular}

${ }^{2} \mathrm{mg} \cdot \mathrm{kg}^{-1}=\mathrm{mmol} \cdot \mathrm{kg}^{-1} \times$ atomic weight.

${ }^{y} \mathrm{~L}=$ linear

$* * * * * *$ Significant at $P \leq 0.05,0.01$, or 0.005 , respectively.

to follow a similar accumulation pattern both years of the study (Table 2). As soil salinity increased, $\mathrm{Cl}$ in the midrib and blade tissues increased. Midribs accumulated between $30 \%$ to $40 \%$ more $\mathrm{Cl}$ than did the surrounding blade tissue at all salinity levels. Sodium accumulation was significantly higher in the blades than in the midribs, while $\mathrm{Ca}$ was higher in midribs at low salinities and higher in blades at high salinities (data not shown).

Although the plants took up an abundance of $\mathrm{Ca}$ under saline conditions, the distribution of $\mathrm{Ca}$ within the plant was predominately to the high-transpiring leaves. Calcium concentration in the leaves was 25 to 30 times higher than in the low-transpiring inner bracts of the buds. Root pressure, which would normally provide a mechanism for $\mathrm{Ca}$ movement to the inner bracts, was severely reduced with increasing soil salinity (Francois et al., 1991). Consequently, with reduced root pressure and low transpiration, a $\mathrm{Ca}$ deficiency occurred in the inner bracts of the buds.

Salinity effects on $\mathrm{Mg}$ and $\mathrm{K}$ content in the leaf blades and midribs have been previously reported (Francois et al., 1991).

This study shows that while artichoke tends to be more salt tolerant than most vegetable crops, the need to maintain low soil salinity levels is essential for maximum yields. When salinity levels become too high, the incidence of $\mathrm{Ca}$ deficiency within the bud increases (Francois et al., 1991) and the size of the buds decreases.

\section{Literature Cited}

Cotlove, E. 1963. Determination of the true chloride content ofbiological fluids and tissues. II. Analysis by simple, non-isotopic methods. Anal. Chem. 35:101-105.

Francois, L.E., T.J. Donovan, and E.V. Maas. 1991 Calcium deficiency ofartichoke buds in relation to salinity. HortScience 26:549-553.

Francois, L.E. and E.V. Maas. 1993. Crop response and management on salt-affected soils, p, 149181. In: M. Pessarakli (ed.). Handbook of plant and crop stress. Marcel Dekker, New York.

Graifenberg, A., M. Lipucci di Paola, and L. Giustiniani. 1993. Yield and growth of globe artichoke under saline-sodic conditions. HortScience 28:791-793.

Maas, E.V. and G.J. Hoffman. 1977. Crop salt tolerance-Current assessment. J. Irrig. Drain. Div. Amer. Sot. Civ. Eng. 103:115-134.

Mayberry, KS. and R.A. Gonzalez. 1992. Vegetable crops: Guidelines to production costs and practices 1992-1993. Univ. of California Coop. Ext. Circ. 104-V.

Ryder, E.J., N.E. DeVoa, and M.A. Bari. 1983. The globe artichoke (Cynara scolymus L.). HortScience 18:646-653.

van Genuchten, M.Th. and G.J. Hoffman. 1984 Analysis of crop salt tolerance data, p. 258-271 In: I. Shainberg and J. Shalhevet (eds.). Soil salinity under irrigation. Process and management. Ecological Studies 51. Springer-Verlag, New York. 